\title{
Immunophenotypic differences between osteoclasts and macrophage polykaryons: Immunohistological distinction and implications for osteoclast ontogeny and function
}

\author{
N A Athanasou, J Quinn
}

\begin{abstract}
The antigenic phenotype of human fetal osteoclasts was compared with that of human tissue macrophages and macrophage polykaryons in foreign body lesions using a large number of monoclonal antibodies directed against myeloid (granulocyte/mononuclear phagocyte) antigens. Osteoclasts expressed a restricted range of macrophage-associated antigens including CD13, CD15A, CD44, CD45, CD54, (ICAM-1), CD71 (transferrin receptor), and CD68. These antigens were also present on macrophages and macrophage polykaryons both of which also strongly expressed CD11a,b,c, CD18, (LFA family), CD14, CD31, CD36, CD37, CD39 and CD43 antigens. There was also weak and occasional expression of CD16 (FcRIII), CD25 (interleukin 2 receptor), CD32 (FcRII), CD35 (C3b receptor) and HLA-DR by macrophage polykaryons.

The presence of some macrophage associated antigens on osteoclasts is consistent with their originating from cells of the mononuclear phagocyte system. The numerous differences in antigenic phenotype between osteoclasts and macrophage polykaryons, however, suggest that their pathways of development and differentiation are not identical. The differences discerned in antigenic phenotype should also permit distinction between these polykaryons (and possibly their mononuclear precursors) in normal and diseased tissues.
\end{abstract}

Cells of the mononuclear phagocyte system are widely distributed throughout the body and have acquired a variety of specialised roles which depend partly on their location and partly on their physiological state of function. Mononuclear phagocyte system cells include mononuclear cells such as blood monocytes and fixed macrophages of various tissues-for example, microglia, and Kupffer cells $^{12}$-as well as multinucleated cells such as foreign body and inflammatory macrophage polykaryons.

Osteoclasts, the specialised multinucleated cells responsible for bone resorption, have also been considered to form part of the mononuclear phagocyte system. ${ }^{34}$ Osteoclasts are formed by fusion of mononuclear precursor cells which are derived from pluripotential haemopoietic stem cells. ${ }^{45}$ The identity of this precursor cell is uncertain but the mono- nuclear phagocyte is thought to be a likely candidate given that it is capable of forming polykaryons which resemble osteoclasts both morphologically and cytochemically. ${ }^{36}$ It is not known whether osteoclasts or mononuclear osteoclast precursors are directly derived from monocytes and macrophages or whether the osteoclast cell lineage diverges at an early stage in monocyte/macrophage development in the bone marrow; alternatively, the osteoclast cell lineage may arise directly from the haemopoietic stem cell and form a completely separate cell lineage in the marrow. ${ }^{48}$

Although there are several ultrastructural and functional differences between osteoclasts and macrophage polykaryons, ${ }^{5910}$ distinction between these cells by light microscopical examination both in vitro and in vivo is often difficult. This difficulty is particularly evident in a variety of pathological conditions of bone where the nature of the multinucleated giant cells is uncertain, such as giant cell tumour of bone, benign chondroblastoma, or non-ossifying fibroma. Osteoclast reacting monoclonal antibodies, in conjunction with immunocytochemical labelling techniques, have been used to identify osteoclasts in vitro and in vivo. ${ }^{11-13}$ Many of these antibodies, however, also react with other cells, including mononuclear phagocyte system cells and macrophage polykaryons, ${ }^{14}$ so that they cannot be regarded as osteoclast specific. Even the function of osteoclasts with regard to bone resorption cannot be regarded as a specific property of the osteoclast as tumour associated macrophage polykaryons exhibit the same feature. ${ }^{15}$

Previous studies have shown that osteoclasts express several specific macrophage associated antigens. ${ }^{16}$ This study seeks to define the antigenic phenotype of the human osteoclast and to determine its relation with that of other marrow derived cells of the myeloid (granulocyte-monocyte) series, in particular, differences in the antigenic phenotype of osteoclasts and macrophage polykaryons. The distinctive patterns of antigenic expression by these two cells should not only aid in the differentiation of osteoclasts from macrophage polykaryons but will also be of interest in terms of osteoclast ontogeny, differentiation, and function.

\section{Methods}

Preparation of imprints containing osteoclasts and cryostat sections of human fetal metaphyseal bone was as previously described. ${ }^{16}$ 
Table 1 Monoclonal antibodies used in this study and their antigen/cell specificity

\begin{tabular}{|c|c|c|c|}
\hline Cluster & Antibodies & $\begin{array}{l}\text { Molecular weight } \\
\text { (kilodaltons) }\end{array}$ & Cell specificity (antigen) \\
\hline CD11a & $\begin{array}{l}\text { MH24, 11H6, CR1S-3, 122-2A5, } \\
\text { BU17, BU49, GRT22, M232, } \\
\text { 0501, MEM25, MEM30, MEM83, } \\
\text { MEM95, 25·3·1, 1L11, 459 } \\
\text { MHM23, MHM24, CLB54, YFC51·1, } \\
\text { YTH81·5, YFC118.3, 1524, 2F12, } \\
\text { F110.22, TMD3-1, ITM3-2, } \\
\text { CC51D7, VIPIIIB , GRF1, HI111, } \\
\text { M10 }\end{array}$ & 180 & Many leucocytes (LFA-1) \\
\hline CD11b & $\begin{array}{l}\text { 44, JML-H11, LPM19C, } \\
\text { 14B6.E2, 5A4.C5, MO1, MN41, } \\
\text { MJ5/1, TMG6-5, VIM12 }\end{array}$ & 155 & $\begin{array}{l}\text { Granulocytes, monocytes; } \\
\text { Mac-1 (CR3:C3b receptor) }\end{array}$ \\
\hline $\begin{array}{l}\text { CD11c } \\
\text { CD13 }\end{array}$ & $\begin{array}{l}\text { 3.9, B-LY6, F9083, S-HCL3, L29 } \\
\text { MoU48, 3D8, WM15, U71, } \\
\text { U81, TJK1 }\end{array}$ & $\begin{array}{l}150 \\
180\end{array}$ & $\begin{array}{l}\text { Granulocytes, monocytes (p150,95) } \\
\text { Granulocytes, monocytes, } \\
\text { macrophages, bile canaliculi, } \\
\text { connective tissues }\end{array}$ \\
\hline CD14 & $\begin{array}{l}\text { CIB-Mon/l, VCHM1, M-M42, } \\
\text { VIM-13, RPA-M1, GR51, } \\
90 \cdot 3,10 \text { G3 3, LOM-01, } \\
\text { JML-H14 }\end{array}$ & 55 & $\begin{array}{l}\text { Monocytes, macrophages, } \\
\text { dendritic reticulum cells }\end{array}$ \\
\hline CD15 & $\begin{array}{l}\text { VIMD } 5,6 \mathrm{~F} 3, \text { bra4F1, L16, } \\
\text { JML-H15 }\end{array}$ & $50-180$ & $\begin{array}{l}\text { Granulocytes, some monocytes, } \\
\text { epithelium, Reed Sternberg cells } \\
\text { (Hapten X) }\end{array}$ \\
\hline CD16 & VEP13, My23 & $50-65$ & $\begin{array}{l}\text { Granulocytes, some monocytes } \\
\text { (FcRIII molecule) }\end{array}$ \\
\hline CD18 & MH23 & 95 & $\begin{array}{l}\text { (Beta-chain of LFA-Mac1-p150,95 family) } \\
\text { Many leucocytes }\end{array}$ \\
\hline CD25 & I 23 cC $1240 / 20$ TM & 55 & $\begin{array}{l}\text { Activated lymphocytes, } \\
\text { macrophages (Interleukin } 2 \text { receptor) }\end{array}$ \\
\hline CD31 & L33, SG-134, 8/32, TM2 & 140 & $\begin{array}{l}\text { Granulocytes, monocytes, } \\
\text { macrophages, platelets, endothelium }\end{array}$ \\
\hline CD32 & MabIV.3, 2E1, CIKM3 & 40 & $\begin{array}{l}\text { Granulocytes, B cells, monocytes, } \\
\text { macrophages, platelets (FCR11-receptor for } \\
\text { IgG) }\end{array}$ \\
\hline CD33 & My9, H153, L4F3 & 67 & $\begin{array}{l}\text { Early myeloid progenitors, } \\
\text { macrophages, AML }\end{array}$ \\
\hline CD34 & My10, B1-3C5 & 115 & $\begin{array}{l}\text { Some myeloid cells, myeloid } \\
\text { progenitors, endothelium }\end{array}$ \\
\hline CD35 & E11, To5, JML-H13 & $220-250$ & $\begin{array}{l}\text { Dendritic reticulum cells, red blood cells, } \\
\text { granulocytes, glomeruli, monocytes (CR1: } \\
\text { C3b receptor) }\end{array}$ \\
\hline $\begin{array}{l}\text { CD36 } \\
\text { CD37 }\end{array}$ & $\begin{array}{l}5 \mathrm{~F} 1 \\
\mathrm{HD} 28\end{array}$ & $\begin{array}{l}85 \\
40-45\end{array}$ & $\begin{array}{l}\text { Monocytes, platelets } \\
\text { B cells, weakly on } \\
\text { macrophages, T cells }\end{array}$ \\
\hline CD39 & G28-10 & 80 & $\begin{array}{l}\text { B cells, macrophages, } \\
\text { endothelium, other cells }\end{array}$ \\
\hline $\begin{array}{l}\text { CD43 } \\
\text { CD44 } \\
\text { CD45 }\end{array}$ & $\begin{array}{l}\text { G19-1 } \\
\text { F-10-44-2 } \\
\text { 124-2H12B, 135-4C5, 135-4H9, } \\
\text { U87, AA44, AB103, AA14, X16, } \\
\text { GRT4, GRT3, GRT2, H130, } \\
\text { BRA55, TL-1, F10-89-4, } \\
\text { BMAC-1, BMAC-2, BMAC-3, } \\
\text { IOR-L3, RP1/10, 03/9, } \\
\text { YTH24.5, YTH54.12, 80.2, 71 } 5 \text {, } \\
\text { GB3, T2/48, TU116, T29/33, } \\
\text { 562/10D3 }\end{array}$ & $\begin{array}{l}120 \\
65-85 \\
200\end{array}$ & $\begin{array}{l}\text { Leucocytes, brain } \\
\text { Leucocytes, brain, red cells } \\
\text { Leucocytes (Leucocyte common antigen) }\end{array}$ \\
\hline CD54 & $8 \mathrm{~F} 5$, My $13, \mathrm{RR} 1 / 1 \cdot 11, \mathrm{LB}-2$ & 85 & (ICAM-1) \\
\hline CD68 & $\begin{array}{l}\mathrm{EBM} / 11, \mathrm{Y}-1 / 82 \mathrm{a}, \mathrm{KiM} 6 \\
\mathrm{Y} 2 / 131, \mathrm{KiM} 7\end{array}$ & 110 & $\begin{array}{l}\text { Pan-mononuclear } \\
\text { phagocyte system, } \\
\text { renal tubular epithelium }\end{array}$ \\
\hline CD71 & $\begin{array}{l}\text { DF1513, VIP-1 } \\
\text { ClII } 147 \\
\text { WK } 32 \mathrm{HK}\end{array}$ & 90 & $\begin{array}{l}\text { Transferrin receptor } \\
\text { Class II MHC (HLA-DR) } \\
\text { Class I MHC (positive control) }\end{array}$ \\
\hline
\end{tabular}

These antibodies, corresponding antigen and tissue distribution are described in reference 18.

Cryostat sections of tissue containing abundant human macrophage polykaryons were also cut. This tissue was derived from the joint capsule removed at surgery for revision arthroplasty of the hip; this capsule contains abundant macrophages and foreign body macrophage polykaryons as part of the inflammatory response to high density polyethylene and acrylic material. ${ }^{17}$ All tissues for cryostat sectioning were received fresh and snap frozen in liquid nitrogen. Cryostat sections were collected on poly-L-lysine coated glass slides, air dried for 24 hours, then fixed in acetone at $4^{\circ} \mathrm{C}$ for 10 minutes and air dried at $22^{\circ} \mathrm{C}$. Bone imprints were allowed to air dry, fixed immediately in cold acetone for 10 minutes, then stored at $-20^{\circ} \mathrm{C}$.

Cryostat sections and bone imprints were stained by an indirect immunoperoxidase technique as previously described. ${ }^{18}$ Anti- bodies were in the form of ascites diluted in hybridoma culture medium to recommended concentrations, or where this was not known, to concentrations of 1 in 100 and 1 in 250 . Negative controls consisted of the addition of culture medium alone without primary antibody. Absence of reactivity with osteoblasts and cartilage cells in cryostat bone sections also served as an internal negative control. Positive controls consisted of antibody to common HLA-A,B,C determinants (WK/32HL).

The monoclonal antibodies used in this study were all taken from the Non-Lineage and Myeloid Panels of the Fourth Internátional Workshop on Human Leucocyte Differentiation Antigens, 1989, and are shown in table 1. The antibodies were grouped into clusters each of which recognise a defined antigen of a similar distinct molecular weight. 
The antibodies were also evaluated for similarities and differences in the pattern of reactivity against marrow, circulating, and tissue fixed granulocytes and mononuclear phagocytes. ${ }^{19}$

\section{Results}

HISTOLOGICAL ASSESSMENT

Both imprints and cryostat sections of metaphyseal bone contained large numbers of osteoclasts. Confirmation that the multinucleated cells in bone imprints are osteoclasts has been shown by their specific morphological response to calcitonin. ${ }^{20}$ Other morphologically identifiable scattered cells in the imprints include erythrocytes, megakaryocytes, platelets, monocytes and granulocytes.

Joint capsule from revision hip arthroplasties contained abundant foreign body material, largely high density polyethylene and acrylic material; the former appears as refractile fragments of foreign material and the latter as rounded empty spaces surrounded by mononuclear histiocytes and foreign body macrophage polykaryons. ${ }^{17}$

Table 2 Summary of antigenic phenotype of osteoclasts and macrophage polykaryons with monoclonal antibodies directed against defined $(C D)$ antigens

\begin{tabular}{|c|c|}
\hline Osteoclasts & $\begin{array}{l}-\mathrm{CD} 13, \mathrm{CD} 44, \mathrm{CD} 45, \mathrm{CD} 54, \mathrm{CD} 68 \\
\text {-CD 15 }\end{array}$ \\
\hline $\begin{array}{l}\text { Macrophage } \\
\text { polykaryons } \dagger\end{array}$ & 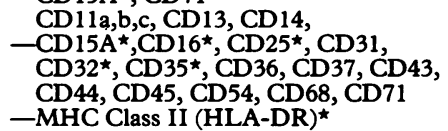 \\
\hline
\end{tabular}

*Indicates weak expression on less than $10 \%$ cells.

† Mononuclear phagocytes in foreign body lesions show the same antigenic phenotype.

Figure 1 Indirect immunoperoxidase staining of bone imprint containing human fetal osteoclasts (bold arrows) showing (A) membrane staining for CD54 (ICAM-1) with monoclonal antibody 8F5; (B) cytoplasmic staining for $C D 68$

(macrophage-associated antigen) with monoclonal antibody Y1/82a; (C) no reaction for $C D 11$ a

(LFA-1) with monoclonal antibody MH24. There are numerous positively stained mononuclear cells (open arrows) in the background.

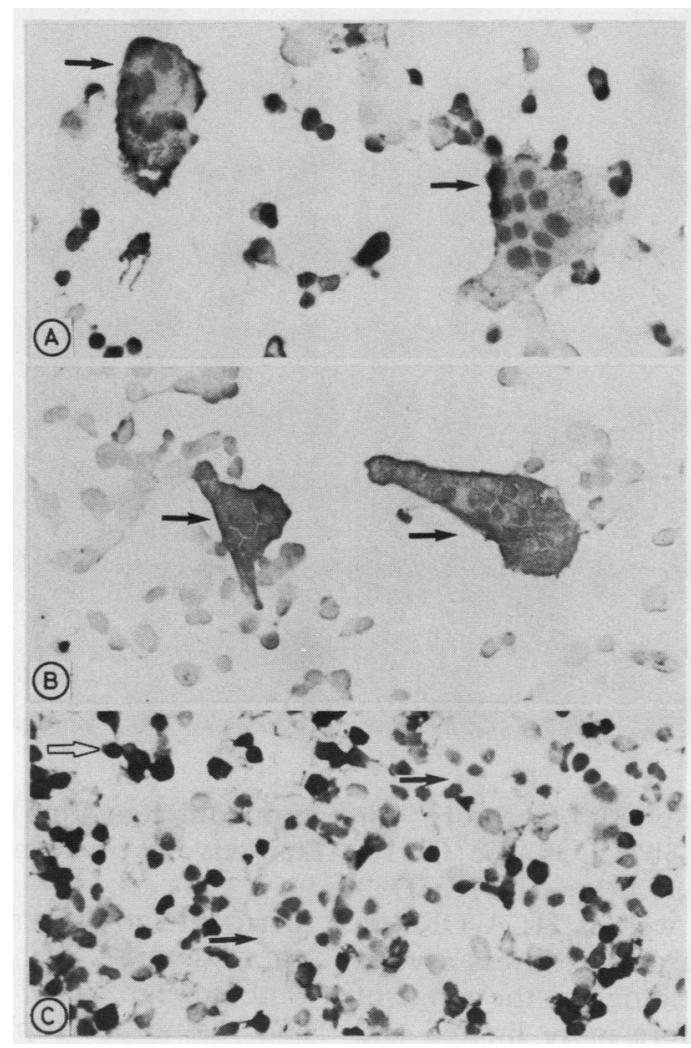

IMMUNOHISTOCHEMICAL STAINING

The results of the immunohistochemical staining of osteoclasts and macrophage polykaryons with monoclonal antibodies to defined antigens are summarised in table 2 . Where a $C D$ antigen is shown as being present on osteoclasts and macrophage polykaryons, it indicates that all the monoclonal antibodies directed against that particular CD antigen (listed in table 1) reacted with the corresponding cell. Although there was strong monoclonal antibody staining of all osteoclasts and macrophage polykaryons for most CD antigens shown in table 2 , the immunohistochemical reaction for several antigens (indicated by an asterisk) was generally weak, and a reaction was only noted on a small percentage of the cells studied. These differences are detailed below.

\section{OSTEOCLAST ANTIGENIC PHENOTYPE}

Osteoclasts in human metaphyseal bone imprints and cryostat sections showed a similar pattern of staining. Evaluation of osteoclast staining in bone imprints was easier, however, as the cells were dispersed and their multinuclearity and cytoplasmic outlines consequently more obvious.

Osteoclasts showed strong membrane staining with monoclonal antibodies to CD13, CD44, CD45 (leucocyte common antigen), CD54 (ICAM-1) (fig 1A), and CD71 (transferrin receptor), and strong cytoplasmic staining with all CD68 antibodies (fig 1B). Osteoclasts were not exclusively stained by these antibodies as in both imprints and cryostat sections mononuclear leucocytes also reacted with these antibodies. Megakaryocytes were easily distinguished from osteoclasts in bone imprints and, with the exception of CD44 and CD68 antibodies, were not stained by the above osteoclast reacting antibodies. Two CD15A antibodies (anti-lacto- $\mathrm{N}$-fucose pentaosyl III or anti-X antibodies chiefly reacting with granulocytes) also weakly stained osteoclasts in fetal bone imprints and cryostat sections. As noted previously, only a few (less than $10 \%$ ) of osteoclasts were stained by CD15A antibodies. ${ }^{15} \mathrm{CD} 15 \mathrm{~A}$ antibodies also stained background mononuclear cells, including granulocytes, but did not react with megakaryocytes or platelets.

All the above osteoclast reacting antibodies were also found to react with macrophage polykaryons (table 2) and to react with monocytes and tissue macrophages in the Workshop analysis. ${ }^{19}$ Results of the Workshop analysis and our own observations of the immunohistochemical staining of fetal bone and lesions containing foreign body giant cells, show that these osteoclast reacting antibodies do not react with monocytes, macrophages, and osteoclasts exclusively; they all react with other marrow derived cells and, in some cases, non-myeloid elements as well (table 1).

Several antigens present on histiocytes and macrophage polykaryons were not expressed by osteoclasts (table 2 ). These include the distinct $\alpha$ chains of the leucocyte function associated family of antigens, CD11a,b,c (LFA-1, CR3 and p150,95, respectively), the 
Figure 2 Indirect immunoperoxidase staining of revision arthroplasty capsule containing refractile foreign material (high density

polyethylene) and foreign body macrophage

polykaryons (arrowed)

showing: (A) membrane staining for CD54

(ICAM-1) with monoclonal antibody $8 F 5$, B) cytoplasmic staining for CD68 (macrophageassociated antigen) with monoclonal antibody KiM6; (C) membrane staining for CD11a (LFA-1) with monoclonal antibody MH24; (D) unstained macrophage polykaryons in negative control for comparison.

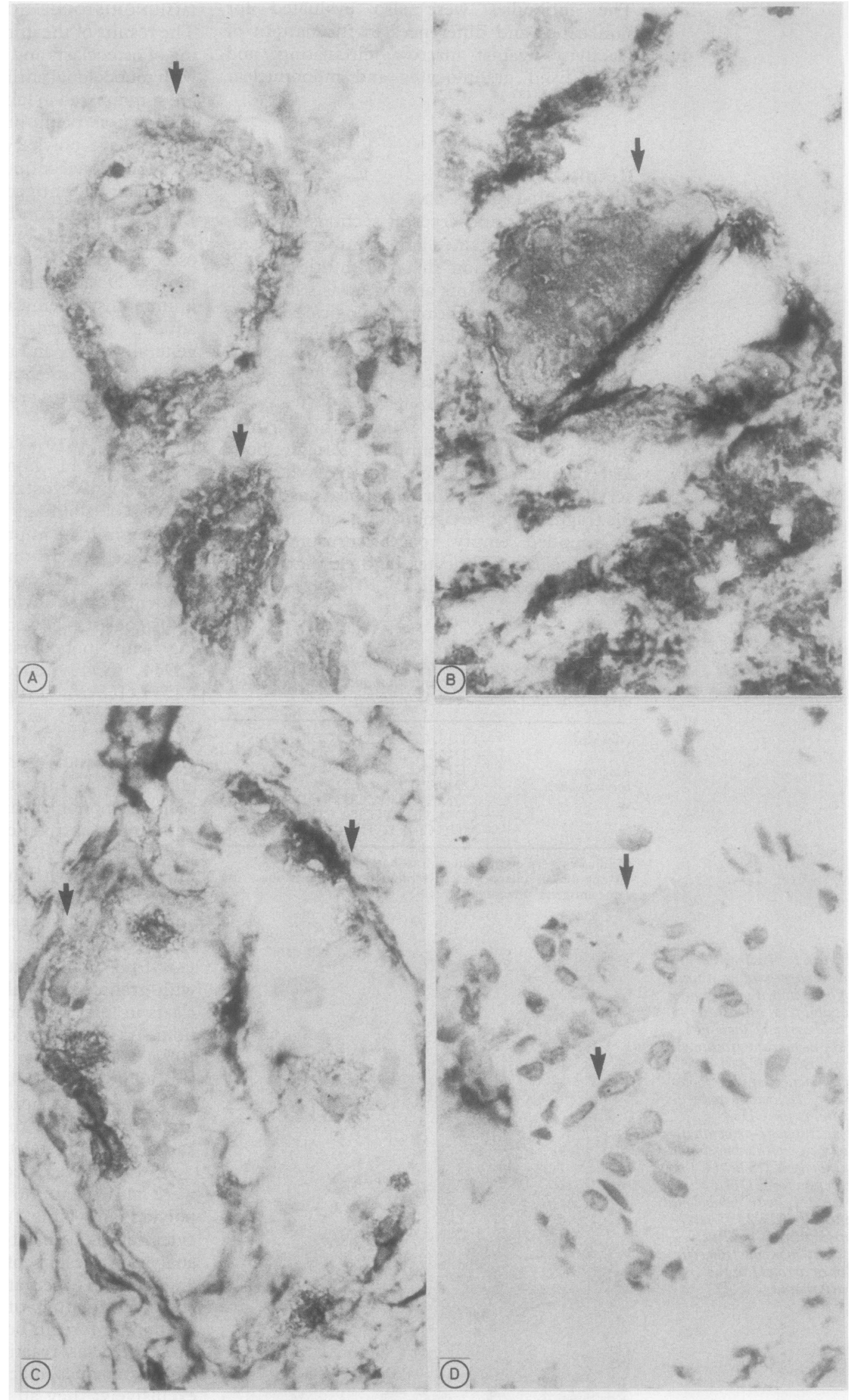

common $\beta$ chain (CD18), receptors for interleukin 2 (CD25), C3b (CD35), Fc (CD16, CD32), and the CD14, CD 36, CD37, CD 39 and CD43 antigens as well as HLA-DR (fig 1C). Although osteoclasts do express several macrophage associated antigens, the range of such antigens is therefore more limited and quite different from that of macrophage polykaryons and tissue macrophages.

\section{ANTIGENIC PHENOTYPE OF MACROPHAGE}

POLYKARYONS

Both foreign body macrophage polykaryons and tissue macrophages in joint capsules 
derived from revision hip arthroplasties reacted with all the monoclonal antibodies directed against the antigens shown in table 2 . All these antibodies, except antibodies CD68, which showed a strong cytoplasmic reaction, predominantly stained the membrane of macrophage polykaryons and tissue macrophages (fig 2A-C). The Workshop analysis showed, and our own results in several cases confirmed, that macrophages and macrophage polykaryons were not exclusively stained by these antibodies. ${ }^{18}$ Staining with antibodies directed against CD15A, CD16, CD32, CD35, and HLA-DR was characterised by a weak membrane reaction of both foreign body macrophage polykaryons and macrophages. In addition, only a low percentage (less than $10 \%$ ) of each of these cells was stained, most remaining unstained.

The range of myeloid antigens expressed by macrophage polykaryons was considerably greater and quite different from that of osteoclasts (table 2) and similar to that of blood monocytes and tissue macrophages according to the Workshop analysis (table 1 ). ${ }^{19}$ The latter findings were confirmed by the staining of macrophage polykaryons and macrophages, which are abundant in revision joint capsules. Staining of macrophage polykaryons was never seen in the absence of macrophage staining and vice versa.

\section{Discussion}

Both osteoclasts and macrophage polykaryons are multinucleated cells which closely resemble each other morphologically at light microscopical examination. ${ }^{3}$ Ultrastructurally, they also show some similarities, although the presence of a plasmalemmal ruffled border and clear zone on osteoclasts clearly distinguishes them from macrophage polykaryons. ${ }^{5}$ These surface distinctions, however, are only found next to the calcified bone matrix and are not seen on osteoclasts detached from the bone surface or in osteoclasts derived from giant cell tumours of bone. ${ }^{5122}$ Both osteoclasts and macrophage polykaryons are derived from circulating mononuclear precursors of haemopoietic origin. In the case of macrophage polykaryons this precursor cell has been established as the blood monocyte. ${ }^{324}$ With regard to osteoclasts, there is considerable evidence to suggest that they are derived from a mononuclear precursor cell of the mononuclear phagocyte system. ${ }^{82526}$ This conclusion is supported by various labelling studies which have shown that mononuclear phagocytes fuse to form osteoclasts, ${ }^{57-29}$ and observations that both monocytes and oesteoclasts are defective in human and murine osteopetrosis. ${ }^{30}{ }^{31}$ There is also evidence to suggest that some peripheral blood monocytes can fuse with purified osteoclasts in vitro. ${ }^{32}$

One of the similarities between osteoclasts and mononuclear phagocytes has been the expression of macrophage associated antigens. 16203334 Several "osteoclast specific" monoclonal antibodies have now been reported in various species ${ }^{11-13}$ but some of these also react with mononuclear phagocyte system and other cells. ${ }^{11-13} \mathrm{~W}$ ith one exception, where the reaction was positive, ${ }^{11}$ their reaction with macrophage polykaryons has not been assessed. With this in mind, we felt it was important to determine the similarities and differences in antigenic phenotype between these two polykaryons. This study has shown that human osteoclasts and macrophage polykaryons do share common surface and cytoplasmic antigens. Both cells express CD45 (leucocyte common antigen), CD13, CD15A (Hapten X), CD44, CD54 (ICAM-1), CD68, and CD71 (transferrin receptor) antigens. These antigens are also expressed by monocytes, macrophages, and macrophage polykaryons, and in some cases other marrow derived cells and even nonmyeloid cells. No human osteoclast specific antigen can therefore be identified. Macrophage polykaryons, in common with tissue macrophages, also express CD11a,b,c, CD18 (LFA antigen family), CD14, CD16 (FcR III receptor molecule), CD25 (interleukin-2receptor), CD31 (FcR II receptor molecule), CD35 (C3b receptor), CD37, CD39, CD43, ad HLA-DR. Osteoclasts, therefore, express several macrophage associated antigens, but the pattern and range of myeloid antigen expression is quite different and more limited than that of macrophage polykaryons and tissue macrophages.

Expression of common surface and cytoplasmic antigens is hardly surprising given the fact that both osteoclasts and macrophage polykaryons have many similarities in terms of origin, structure, cytochemistry and function. ${ }^{4}$ Leucocyte common antigen (CD45) is expressed on the cell membrane of all leucocyte progeny of the haemopoietic stem cell and has previously been reported on osteoclasts ${ }^{345}$ and macrophage polykaryons. ${ }^{35}$ The CD13 monoclonal antibodies recognise a 150 kilodalton membrane glycoprotein present on normal and malignant myeloid cells as well as other nonmyeloid cells such as renal tubular epithelium and bile duct epithelium. ${ }^{19}{ }^{36} \mathrm{CD} 13$ antigen is thought to be aminopeptidase $\mathrm{N}$, a membrane bound glycoprotein involved in the metabolism of regulatory peptides by diverse cell types including macrophages and granulocytes. ${ }^{37}$ Both cells also express the CD44 antigen found on other leucocytes and in a wide variety of tissue types ${ }^{1938}$ and the CD71 transferrin receptor; this has previously been noted on mononuclear phagocytes (including Kupffer cells) as well other non-marrow-derived cell types. ${ }^{39} \mathrm{CD} 68$ monoclonal antibodies, formerly classified as group $12 \mathrm{~A},{ }^{36}$ have a high affinity and specificity for cells of the mononuclear phagocyte system, ${ }^{19}{ }^{36-42}$ including the diverse tissue specific mononuclear phagocyte system cells such as microglia and Langerhans' cells. They also react with megakaryocytes and platelets $^{1620}$ as well as renal tubular epithelium. ${ }^{19}{ }^{36}$ These antibodies recognise an antigen of 110 kilodaltons molecular weight expressed in the cytoplasm and on the cell membrane. ${ }^{19434}$ The fact that osteoclasts also express the CD68 and other monocyte-macrophage associated $\mathrm{CD}$ antigens would argue 
against the development of osteoclasts being entirely separate from that of monocytes and macrophages and corroborates their membership of the mononuclear phagocyte system.

The antigens present on macrophage polykaryons and not on osteoclasts are equally of great interest. These differences in antigenic phenotype reflect differences in the differentiation pathway and function of the two cells. Macrophage polykaryons have an antigenic phenotype which is similar to that of monocytes and tissue macrophages. This was confirmed not only by the Workshop analysis ${ }^{18}$ but also by the parallel staining of histiocytes in the foreign body lesions examined in this study. Several in vitro studies have shown that foreign body giant cells are formed by the fusion of mononuclear phagocytes 32324 and the findings of this study, which show a similar immunophenotype on the two cells in the one lesion, are consistent with this phenomenon.

Like mononuclear phagocytes, macrophage polykaryons express the $\beta$ - 2 integrins or LFA family of antigens. This is a family of cellsurface molecules that are important in intercellular adhesion. These molecules consist of three non-covalently associated heterodimers with distinct $\alpha$ chains of molecular weights of 180 kilodaltons (LFA-1), 165 kilodaltons (Mac-1), and 150 kilodaltons (p150/95) and a common $\beta$ chain. ${ }^{46}$ These distinct $\alpha$ subunits are respectively clustered as CD11a, CD11b, CD11c, and the common $\beta$ chain as CD18; they are present on mononuclear phagocytes and other myeloid cells. Osteoclasts do not express these antigens but do express CD54 or the intercellular adhesion molecule (ICAM-1), a 90 kilodalton inducible surface glycoprotein which is the ligand for LFA-1 ${ }^{478}$ This would suggest that direct interaction between other leucocytes and osteoclasts is possible through an LFA-1/ICAM-1 receptor-ligand pairing: this may be one mechanism whereby these cells can modulate osteoclast function. In this regard it is also relevant to note that osteoclasts possess receptors for $\alpha$ and $\beta$ chains of integrins such as the vitronectin receptor ${ }^{49-51}$; there is some structural homology between $\beta$ and $\alpha$ chains of these integrins and LFA- $1 .{ }^{52}$

Several receptors, some of which are important in phagocytosis and endocytosisfunctions exhibited by both osteoclasts and macrophage polykaryons-were weakly and inconsistently expressed by foreign body giant cells and not at all by osteoclasts. These include two receptors for the portion of immunoglobulin-FcR II (CD32) and FcR III (CD16) -and the CR1 receptor for C3b (CD35). The low prevalence and weak expression of these receptors on giant cells in the joint capsules studied may be a consequence of loss of such membrane components during the process of cell fusion as suggested by Papadimitriou and Walters. ${ }^{45}$ As a similar pattern of staining was observed in surrounding macrophages, however, this pattern of expression is more likely to be due to functional considerations, possibly related to the antigenic material (high density polyethylene and methacrylate) to which the cells are exposed. Weak and low frequency staining for HLA-DR and CD25 could similarly underlie expression of these antigens associated with macrophage activation. Absence of HLA-DR in foreign body and other giant cell lesions has been noted previously. ${ }^{53}$ Weak and low frequency expression of CD15A by both osteoclasts and foreign body macrophage polykaryons may also be determined by functional considerations. In contrast, all macrophage polykaryons were stained by CD14 monoclonal antibodies; this is strongly expressed in mononuclear phagocytes, particularly monocytes, as well as interdigitating reticulum cells, Langerhans' cells, tissue macrophages, some granulocytes and endothelial cells. ${ }^{196}$ Other antigens, CD15A, CD31, CD36, CD37, CD39, and CD44 found on macrophage polykaryons, are also known to be expressed by mononuclear phagocytes, other leucocytes, and some non-myeloid cells (table 1).

Although our results show that osteoclasts express some antigenic markers characteristic of mononuclear phagocyte system cells, they also show that numerous differences in antigenic phenotype exist between osteoclasts and both mononuclear phagocytes and macrophages polykaryons. One possible explanation for the antigenic similarities and differences that we found between osteoclasts and macrophage polykaryons is that proliferation and development of osteoclast precursors may become separate from that of macrophages and macrophage polykaryons at an early stage in haemopoietic tissue. This could account for the preservation of some phenotypic characteristics of monocytes and macrophages. There is now considerable evidence from in vitro studies to suggest that osteoclasts and monocyte/macrophages share a common early progenitor such as the monoblast or promonocyte. ${ }^{785}$ Alternatively, local factors in the complex bone microenvironment and functional considerations could account for the differences in antigenic phenotype among osteoclasts, mononuclear phagocytes, and macrophage polykaryons. If this is the case then such local conditions or the process of fusion of tissue macrophages in bone result in the loss of many surface molecules including several fundamental, widely distributed mononuclear phagocyte system antigens. This is certainly not the case with macrophage polykaryons, where the antigenic phenotype of the polykaryons and surrounding mononuclear phagocytes in the giant cell lesions is identical.

Differences in the antigenic phenotype between osteoclasts and macrophage polykaryons may also provide a means whereby these two polykaryons can be distinguished in tissue sections. As no human osteoclast specific antigen has been identified an osteoclast is probably best defined and distinguished from a macrophage polykaryon by the macrophage associated antigens it does not express such as CD11a, b, c, CD18, and CD14. Thus, as with the immunocytochemical definition of most leucocytes, a panel of several monoclonal antibodies directed against different antigens is best used to identify accurately and distinguish 
morphologically similar cells such as the osteoclast and macrophage polykaryons. This information may also be of use for defining the mononuclear precursors of these polykaryons or of cultured osteoclast-like cells formed in long term bone marrow culture. ${ }^{55}$ They should also aid in the characterisation of multinucleated giant cells in giant cell lesions of bone and soft tissues.

We thank Miss $\mathrm{L}$ Watts for typing the manuscript. NAA is an Arthritis and Rheumatism Council Fellow in Pathology. This study was funded in part by the Cancer Research Campaign and the University of Oxford.

1 van Furth $R$. Cells of the mononuclear phagocyte system nomenclature in terms of sites and conditions. In: van Furth R, ed. Mononuclear phagocytes. The Hague: Martinus Nijhoff, 1980:1-30

2 Lasser A. The mononuclear phagocytic system. Hum Pathol 1983;14:108-26.

3 Chambers TJ. Multinucleate giant cells. J Pathol 1976; 126:125-48

4 Chambers TJ. The cellular basis of bone resorption. Clin Orthop 1980;151:283-93.

5 Gothlin G, Ericsson JLE. The osteoclast. Clin Orthop 1976;120:201-31.

6 Dorey CK, Bick KL. Ultrahistochemical analysis of glycosaminoglycan hydrolysis in the rat periodontal ligament I. Evidence for macrophage involvement in bone remodelling. Calcif Tissue Res 1977;24:135-41.

7 Nijweide PJ, Burger EH, Feyen JHM. Cells of bone: proliferation, differentiation and hormonal regulation. Physiol Rev 1986;66:855-85.

8 Mundy GR, Roodman GD. Osteoclast ontogeny and function. In: Peck WA, ed. Bone and mineral research No 5. Amsterdam: Elsevier, 1987:209.

9 Chambers TJ, Magnus CJ. Calcitonin alters behaviour of isolated osteoclasts. J Pathol 1982;136:27-39.

10 Chambers TJ. The pathobiology of the osteoclast. $J$ Clin Pathol 1985;38:241-52.

11 Horton MA, Lewis D, McNulty K, Pringle JAS, Chambers TJ. Monoclonal antibodies to osteoclastoma (giant cell bone tumours): definition of osteoclast specific cellular antigens. Cancer Res 1985;45:5663-9.

12 Nijweide PJ, Vrigherd Hammers T, Mulder RJP, Blok J. Cell surface antigens on osteoclasts and related cells in the quail studied with monoclonal antibodies. Histochemistry 1985;83:315-24.

13 Oursler MJ, Bell LV, Clevingen B, Osdoby P. Identification of osteoclast specific monoclonal antibodies. J Cell Biol 1985;100:1592-600.

14 Athanasou NA, Quinn J, Horton MA, McGee J O'D. New sites of cellular vitronectin receptor immunoreactivity sites of cellular vitronectin receptor immunoreactivity
detected with osteoclast-reacting monoclonal antibodies detected with osteoclast-reacting monoclonal an
$13 \mathrm{C} 2$ and 23C6. Bone and Mineral 1990;8:7-22.

15 Athanasou NA, Wells CA, Quinn J, Ferguson DP, Heryet A, McGee J O'D. The origin and nature of stromal osteoclast-like multinucleated giant cells in breast carcinoma: implications for tumour osteolysis and macrophage biology. Br J Cancer 1989;59:491-8.

16 Athanasou NA, Quinn J, McGee J O'D. Immunocytochemical analysis of the human osteoclast: phenotypic relationship to other marrow-derived cells Bone and Mineral 1988;3:317-33.

17 Revell PA. Tissue reactions to joint prostheses and the products of wear and corrosion. In: Berry CL, ed. Current trends in pathology: Bone and joint diseases. Berlin: trends in pathology: Bone and

18 Gatter KC, Falini B, Mason DY. The use of monoclonal antibodies in histopathological diagnosis. In: Anthony PP, MacSween RNM, eds. Recent advances in histopathology. No 12. Edinburgh: Churchill Livingstone, 35-67.

19 Knapp W, Dorken B, Rieber P, Schmidt RE, Stein H, von den Borme AEGK, eds. Leucocyte typing IV. Oxford: Oxford University Press, 1989.

20 Athanasou NA, Heryet A, Quinn J, Gatter KC, Mason DY, McGee J O'D. Osteoclasts contain macrophage and megakaryocyte antigens. J Pathol 1986;150:239-46.

21 Hanaoka H, Friedman B, Mack RD. Ultrastructure and histogenesis of giant cell tumour of bone. Cancer 1970; 25:1408-23.

22 Aparisi T. Giant cell tumour of bone. Acta Orthop Scand 1978;(Suppl 173): 1-37.

23 Sutton JS, Weiss L. Transformation of monocytes in tissue culture into macrophages, epithelioid cells and multinucleated giant cells. J Cell Biol 1966;28:303-29.

24 Mariano M, Spector WG. The formation and properties of macrophage polykaryons (inflammatory giant cells). J Pathol 1974;113:1-19.
25 Marks SC. The origin of osteoclasts. J Oral Pathol 1983; 12:226-56.

26 Nijweide PJ, Burger EH, Feyen JHM. Cells of bone: proliferation, differentiation and hormonal regulation. Physiol Rev 1981;66:855-86.

27 Fischman DA, Hay ED. Origin of osteoclasts from mononuclear leukocytes in regenerating newt limbs. Anatomical Research 1962;143:329-35.

28 Jee WS, Nolan PO. Origin of osteoclasts from fusion of phagocytes. Nature 1963;200:225-6.

29 Tinkler SMB, Williams DM, Johnson NW. Osteoclast formation in response to intraperitoneal injection of alpha hydroxycholecalciferol in mice. $J$ Anat 1981;233:91-7.

30 Coccia PF, Krivit W, Cervenka J, et al. Successful bonemarrow transplantation for infertile malignant osteopetrosis. N Engl J Med 1980;302:701-8.

31 Marks SC. Congenital osteopetrotic mutations as probes of the origin, structure and function of osteoclasts. Clin Orthop 1984;189:239-63.

32 Zambonin Zallone A, Teti A, Primavera MV. Monocytes from circulating blood fuse in vitro with purified osteoclasts in primary culture. J Cell Sci 1984;66:335-42.

33 Siminia T, Dijkistra CD. The origin of osteoclasts: an immunohistochemical study on macrophages and osteoclasts in embryonic rat bone. Calcif Tissue Int 1986; 39:263-6.

34 Brecher M, Franklin WA, Simon MA. Immunohistochemical study of mononuclear phagocyte antigens in giant cell tumor of bone. Am J Pathol 1986;125:252-7.

35 Athanasou NA, Quinn J, McGee J O'D. Leucocyte common antigen is present on osteoclasts. J Pathol 1987:1 53:121-6.

36 Hogg N, Horton MA. Myeloid antigens: new and previously defined clusters. In: McMichael A, Beverley PCL, Cobbold S, eds. Leucocyte typing III. Oxford: Oxford University Press, 1987:576-602.

37 Look AT, Ashmun RA, Shapiro LH, Peiper SC. The human myeloid plasma membrane glycoprotein $\mathrm{CD} 13$ (gp150) is identical to aminopeptidase N. Tissue Antigens 1989; 33:228.

38 Dalchau R, Flanagan BF, Allen AK, Daar AS, Fabre JW. Chemical composition and tissue distribution of the human CDw44 glycoprotein. Tissue Antigens 1989; 33:269.

39 Gatter KC, Brown G, Trowbridge IS, Woolston RE, Mason DY. Transferrin receptors in human tissues: their distribution and possible clinical relevance. J Clin Pathol distribution and

40 Parwaresch MR, Radzun HJ, Kreipe H, Hansmann M-L, Barth J. Monocyte-macrophage reactive monoclonal antibody $\mathrm{Ki}-\mathrm{M} 6$ recognises an intracytoplasmic antigen. Am J Pathol 1986;124:141-51.

41 Kelly PMA, Bliss E, Morton JA, Burns J, McGee J O'D. Monoclonal antibody EBM/11: high cellular specificity for human macrophages. J Clin Pathol 1988;41:510-5.

42 Davey FR, Cordell JL, Erber WN, Pulford KA, Gatter KC, Mason DY. Monoclonal antibody (Y1/82A) with specificity towards blood monocytes and tissue macrophages. J Clin Pathol 1988;41:753-8.

43 Cordell J, Simmons D, Micklem K, Stross P, Mason DY. The expression of pan-macrophage antigens in transfected cells. Tissue Antigens 1989;33:204.

44 Micklem K, Rigney E, Pulford K, Turley H, Mason DY. Four pan-macrophage antibody from the Third Workshop recognise the same antigen. Tissue Antigens 1989; 33:206.

45 Papadimitriou JM, Walters MN-I. Macrophage polykaryons. CRC Crit Rev Toxicol 1979;6:211-55.

46 Sanchez Madrid F, Nagy JA, Robbins E, Simon P, Springer TA. A human leukocyte differentiation antigen family with distinct $\alpha$-subunits and a common $\beta$-subunit. $J$ Exp Med 1983;1 158:1785-803.

47 Staunton DE, Marlin SD, Stratrowa C, Dustin ML, Springer TA. Primary structure of ICAM-1 demonstrates Springer.TA. Primary structure of ICAM-1 demonstrates integrin supergene family. Cell 1988;52:925-33.

48 Rothlein R, Dustin ML, Maerlin SD, Springer TA. A human intercellular adhesion molecule (ICAM-1) distinct from LFA-1. J Immunol 1986;137:1270-4.

49 Horton MA. Osteoclast specific antigens. ISI Atlas of Science: Immunology 1988;1:35-43.

50 Davies J, Warwick J, Totty N, Philp R, Helfrich M, Horton $M A$. The osteoclast functional antigen, implicated in the regulation of bone resorption is biochemically related to the vitronectin receptor. J Cell Biol 1989;109:1817-26.

51 Athanasou NA, Quinn J, Heryet A, McGee J O'D. Localisation of platelet antigens and fibrinogen on osteoclasts. tion of platelet antigens

52 Hynes RO. Integrins: a family of cell surface receptors. Cell 1987;48:549-54.

53 Regezi JA, Zarbo RJ, Lloyd RV. HLA-DR antigen detection in giant cell lesions. J Oral Pathol 1986;15:434-8.

54 Marks SC, Popoff SN. Bone cell biology: the regulation of development, structure and function in the skeleton. Am J Anat 1988;183:1-44.

55 Kukita T, McManus LM, Miller M, Civin C, Roodman GD. Osteoclast-like cells formed in long-term human bone marrow cultures express a similar surface phenotype as authentic osteoclasts. Lab Invest 1989;60:532-8. 